\title{
Rapsyn Clusters Neuronal Acetylcholine Receptors But Is Inessential for Formation of an Interneuronal Cholinergic Synapse
}

\author{
Guoping Feng, ${ }^{1}$ Joe Henry Steinbach, ${ }^{2}$ and Joshua R. Sanes ${ }^{1}$ \\ Departments of ${ }^{1}$ Anatomy and Neurobiology and ${ }^{2}$ Anesthesiology, Washington University School of Medicine, St. Louis, \\ Missouri 63110
}

Nicotinic acetylcholine receptors (AChRs) are clustered at high density in the postsynaptic membranes of skeletal neuromuscular junctions and cholinergic interneuronal synapses. A cytoplasmic protein, rapsyn, is essential for AChR clustering in muscle. Here, we asked whether rapsyn mediates neuronal AChR clustering at cholinergic synapses in a mammalian sympathetic ganglion, the superior cervical ganglion (SCG). Several observations supported this possibility: (1) AChR clusters containing the $\alpha 3-5$ and $\beta 2$ subunits, homologs of the muscle AChR subunits, are present at SCG synapses; (2) rapsyn RNA is readily detectable in the SCG; and (3) expression of recombinant rapsyn in heterologous cells induces aggregation of coexpressed neuronal AChR subunits. However, rapsyn protein was undetectable at ganglionic synaptic sites. Moreover, ag- gregates of neuronal AChRs induced in heterologous cells by full-length rapsyn remained intracellular, whereas rapsyninduced clusters of muscle AChRs reached the cell surface. Additional studies revealed a second rapsyn RNA species in SCG generated by alternative splicing and competent to encode a novel short rapsyn isoform. However, this isoform clustered neither neuronal nor muscle AChRs in heterologous cells. Most telling, the number, size, and density of AChR clusters in SCG did not differ significantly between neonatal mice bearing a targeted mutation of the rapsyn gene and littermate controls. Thus, rapsyn is dispensable for clustering of ganglionic neuronal nicotinic AChRs.

Key words: acetylcholine receptor; knock-out; mouse; postsynaptic; rapsyn; superior cervical ganglion; synaptogenesis
Neurotransmitter receptors are clustered in the postsynaptic membrane at many, if not all, chemical synapses. The high density of receptors is crucial for synaptic function, and regulation of receptor density may underlie some forms of synaptic plasticity. Proteins have now been identified that interact with the cytoplasmic domains of various receptors and appear to play roles in the clustering process. These include gephyrin for glycinergic receptors (Kirsch et al., 1996), the PSD/SAP proteins (PSD95/SAP90, PSD93/chapsyn-110, SAP97, and SAP102) for NMDA-type glutamate receptors (Cho et al., 1992; Kistner et al., 1993; Niethammer et al., 1996; Kornau et al., 1997), Glutamate Receptor Interacting Protein (GRIP) for AMPA-type glutamate receptors (Dong et al., 1997), Homer for metabotropic glutamate receptors (Brakeman et al., 1997), and rapsyn for nicotinic acetylcholine receptors (AChRs) at the skeletal neuromuscular junction.

Rapsyn, on which we focus here, is a $43 \mathrm{kDa}$ cytoplasmic protein that was originally identified by virtue of its close association with the AChRs of Torpedo electric organ (Sobel et al., 1977; Neubig et al., 1979). Rapsyn is also codistributed with AChRs at the neuromuscular junction; rapsyn and AChRs appear together at the earliest stages of synaptogenesis and are present at 1:1 stoichiometry at adult synapses (Froehner et al., 1981; LaRo-

Received Feb. 11, 1998; revised March 17, 1998; accepted March 19, 1998.

This work was supported by grants from National Institutes of Health to J.R.S. and J.H.S. and a McKnight Scholar Award to J.R.S. G.F. is a Fellow of the Jane Coffin Childs Memorial Fund for Medical Research. We thank Elizabeth Apel and Bruce Patton for advice, Kathy Buckley and Jon Lindstrom for antibodies, Jim Patrick and Keith Isenberg for nicotinic subunit cDNA clones, Renate Lewis, Carrie Kopta, and Jessie Zhang for assistance, and Monica McCullough for initial studies of receptor distribution on the stably transfected cell line.

Correspondence should be addressed to Dr. Joshua R. Sanes, Department of Anatomy and Neurobiology, Washington University School of Medicine, 660 South Euclid Avenue, Box 8108, St. Louis, MO 63110.

Copyright (ㄷ) 1998 Society for Neuroscience $\quad 0270-6474 / 98 / 184166-11 \$ 05.00 / 0$ chelle and Froehner, 1986; Noakes et al., 1993). That rapsyn is sufficient to cluster AChRs was shown by coexpression of recombinant protein in nonmuscle cells: AChRs are diffusely distributed when expressed on their own but become aggregated into high-density clusters when coexpressed with rapsyn (Froehner et al., 1990; Phillips et al., 1991a). That rapsyn is necessary for synaptogenesis was shown genetically in mice: no AChR clusters form at neuromuscular junctions of mice bearing a targeted mutation of the rapsyn gene, and homozygous mutants die of respiratory failure within a few hours of birth (Gautam et al., 1995).

To date, no information is available on the mechanisms that induce clustering of nicotinic AChRs at interneuronal synapses. We have undertaken to address this issue at the relatively accessible synapse formed by autonomic preganglionic axons on sympathetic neurons in the superior cervical ganglion (SCG) of the mouse. Because neuronal and muscle nicotinic AChR subunits are similar in primary sequence (Lindstrom, 1996), we began by testing the possibility that rapsyn might play a crucial role in neurons as it does in muscle. We show here that sympathetic neurons express RNAs encoding both full-length rapsyn and a novel shorter isoform generated by alternative splicing. Moreover, rapsyn can induce aggregation of neuronal AChRs coexpressed in heterologous cells. However, three lines of evidence indicate that rapsyn is not a critical mediator of AChR clustering at ganglionic synapses. First, rapsyn protein is undetectable at AChR clusters in the SCG. Second, although rapsyn formed clusters with both muscle and neuronal AChRs in heterologous cells, only the former were transported to the plasma membrane. Third, and most telling, both synaptic and nonsynaptic AChR clusters formed in SCGs of rapsyn-deficient mutant mice. 


\section{MATERIALS AND METHODS}

Animals. Sympathetic ganglia, skeletal muscles, and brains were dissected from timed embryonic or postnatal mice. Mice bearing a targeted mutation of the rapsyn gene have been described previously (Gautam et al. 1995) and were maintained on a 129SV $\times$ C57BL6 hybrid background. Homozygous mutants were readily identified because they died within a few hours of birth, but their genotype was confirmed by PCR. Littermates of the rapsyn mutants or wild-type C57BL6 (The Jackson Laboratory, Bar Harbor, ME) or ICR mice (Harlan Sprague Dawley, Indianapolis, IN) were used as controls.

Antibodies. Four rat monoclonal antibodies to AChR subunits were obtained from Jon Lindstrom (University of Pennsylvania) and from the Developmental Studies Hybridoma Bank (Iowa City, IA). Monoclonal antibody (mAb) 35 recognizes mouse AChR $\alpha(\alpha 1)$ subunit; mAb 210 recognizes mouse $\mathrm{AChR} \alpha 1$ and $\alpha 5$ subunits; mAb 299 recognizes mouse $\mathrm{AChR} \alpha 4$ subunit; and mAb 270 recognizes mouse AChR $\beta 2$ subunit (Lindstrom, 1996). Two additional mouse monoclonal antibodies against $\alpha$ subunits (mAb 398 and mAb 399; Chemicon, Temecula, CA) and a polyclonal antibody to $\alpha 3$ subunit (AChR $\alpha 3$; Santa Cruz Biotechnology, Santa Cruz, CA) were also tested but did not detectably stain SCG. Monoclonal antibody to the synaptic vesicle protein SV2 was a gift from Kathleen Buckley (Harvard Medical School, Boston, MA) (Buckley and Kelly, 1985). mAb 7a to gephyrin was a gift from Heinrich Betz (MaxPlanck-Institute for Brain Research) (Kirsch and Betz, 1993). Affinitypurified rabbit anti-rapsyn polyclonal antibody 5943 and mouse antirapsyn mAb 1234 were described previously (Phillips et al., 1991b). Rabbit antibodies to mouse laminin 1 and rat neural cell adhesion molecule (NCAM) were generated in our laboratory. Secondary antibodies included FITC-goat anti-rat (Organon Teknika-Cappel, West Chester, PA), Cy3-goat anti-rat and Cy3-goat anti-rabbit (Jackson ImmunoResearch, West Grove, PA), and FITC-goat anti-mouse IgG1 and FITC-goat anti-rabbit (Boehringer Mannheim, Indianapolis, IN).

Reverse transcription-PCR. Total RNA was extracted using the guanidinium-acid-phenol method (Chomczynski and Sacchi, 1987). Poly $\left(\mathrm{A}^{+}\right)$ RNA was isolated by a single passage over an oligo-dT-cellulose column. First-strand cDNA was synthesized using avian myeloblastosis virus reverse transcriptase (Promega, Madison, WI) and $10 \mu \mathrm{g}$ of total RNA or $2 \mu \mathrm{g}$ of poly $\left(\mathrm{A}^{+}\right)$RNA in a $50 \mu \mathrm{l}$ reaction. For amplification of rapsyn, a forward primer [J23; GGGCAGGACCAGACAAAGCAAC, nucleotides (nt) 110-131] and a reverse primer (R5; CCGATGGATATCGGCAAAGC, nt 858-877) were designed. For better separation of the splicing form from the original rapsyn, a second forward primer was used (F2; GAGATGGGCCGCTACAAAGAGATGCT, nt 269-294). The 50 $\mu$ l PCR mixture contained $5 \mu$ l of first-strand cDNA from total RNA (or $1 \mu \mathrm{l}$ if synthesized from mRNA), $0.2 \mathrm{~mm}$ deoxynucleotide triphosphates, $10 \mathrm{~mm}$ Tris-HCl, $\mathrm{pH} 8.3,50 \mathrm{~mm} \mathrm{KCl}, 1.5 \mathrm{~mm} \mathrm{MgCl}_{2}$, a $0.1 \mu \mathrm{M}$ concentration of each primer, and $1.25 \mathrm{U}$ of Taq polymerase (Life Technologies, Gaithersburg, MD). The PCR was performed under the following conditions: $94^{\circ} \mathrm{C}$ for $1 \mathrm{~min}, 55^{\circ} \mathrm{C}$ for $1 \mathrm{~min}$, and $72^{\circ} \mathrm{C}$ for $2 \mathrm{~min}$ for 40 cycles, followed by a $10 \mathrm{~min}$ final extension at $72^{\circ} \mathrm{C}$. PCR products were purified from $1 \%$ agarose gels, subcloned into pBluescript II SK ${ }^{+}$(Stratagene, La Jolla, CA), and sequenced using the dideoxy terminator method and an automated sequencer.

Expression vectors. The cDNAs for the rat neuronal nicotinic subunits were kindly provided by Dr. J. Patrick (Baylor College of Medicine, Houston, TX). Those for the $\alpha 4$ subunit (HYA23-1E; Goldman et al., 1987) and $\beta 2$ subunit (PCX49; Deneris et al., 1988) were transferred to pcDNA3 (Invitrogen, San Diego, CA) for expression. Keith Isenberg (Washington University School of Medicine. St. Louis, MO) kindly provided a construct containing the rat $\alpha 3$ subunit (PCA48E; Boulter et al., 1986) in pRc-CMV (Invitrogen). Expression constructs encoding mouse muscle AChR $\alpha, \beta, \gamma$, and $\delta$ subunits and mouse rapsyn were described previously (Phillips et al., 1991a; Maimone and Merlie, 1993; Apel et al., 1995). (We use generally accepted nomenclature and refer to the muscle subunits as $\alpha$ and $\beta$ rather than $\alpha 1$ and $\beta 1$.) An expression construct encoding a short form of rapsyn was generated by replacing the

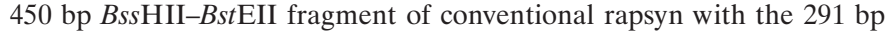
BssHII-BstEII fragment from the short form that had been isolated by PCR, as described above.

Cell culture. For transfection, QT-6 fibroblasts [American Type Culture Collection (ATCC), Manassas, VA] were plated onto 13-mmdiameter glass coverslips in $35 \mathrm{~mm}$ tissue culture dishes and cultured until $50 \%$ confluent. Cells were transfected using the calcium phosphate precipitation method (Chen and Okayama, 1987). For each $35 \mathrm{~mm}$ dish, $2.5 \mu \mathrm{g}$ of each plasmid was used, and pBluescript II SK ${ }^{+}$was added as necessary to bring the total amount of DNA to $12.5 \mu \mathrm{g} / 35 \mathrm{~mm}$ dish to equalize transfection efficiency. Cells were stained 40-48 hr after transfection.

HEK293 cells (CRL-1573; ATCC) were transfected by electroporation with expression constructs for the rat $\alpha 4$ and $\beta 2$ subunits. Transfected cells were selected in medium containing G418 $(450 \mu \mathrm{g} / \mathrm{ml}$; Life Technologies). Drug-resistant cells were maintained in G418 and then repeatedly immunoselected (Chen et al., 1995) using mAb 270, which binds to an epitope on the extracellular surface of the $\beta 2$ subunit (Whiting et al., 1987). The cells we used had been selected sequentially eight times but had not been cloned. Membranes prepared from these cells bind cytisine with high affinity (apparent $K_{\mathrm{d}}, 0.1 \mathrm{nM}$ ), and binding can be completely inhibited by nicotine (K. Burris and J. H. Steinbach, unpublished observations). Patch-clamp recordings demonstrate that the cells produce conductance increases to nicotinic agonists (acetylcholine, nicotine, and dimethylphenylpiperazinium) that can be blocked by dihydro- $\beta$ erythroidine (K. Burris, K. Paradiso, and J. H. Steinbach, unpublished observations). For transient expression of rapsyn, HEK293 cells were transfected as described for QT-6 cells, except that the cells were plated on $0.1 \mathrm{mg} / \mathrm{ml}$ poly-L-lysine-coated coverslips.

PC12 cells were cultured in DMEM with $10 \%$ fetal calf serum, $5 \%$ horse serum, and $7 \% \mathrm{CO}_{2}$. For neuronal differentiation, cells were treated with $50 \mathrm{ng} / \mathrm{ml} 2.5 \mathrm{~S}$ mouse NGF (a gift from Eugene Johnson, Washington University) for $7 \mathrm{~d}$, and then RNA was extracted as described above.

Immunohistochemistry. Tissues from mutant or control mice were embedded in Tissue-Tek OCT compound (Sakura Finetek USA, Torrance, CA), frozen in liquid nitrogen-cooled isopentane, and sectioned at $10 \mu \mathrm{m}$ in a cryostat. Sections were blocked with $2 \%$ BSA and $10 \%$ normal goat serum in PBS for $1 \mathrm{hr}$, incubated with primary antibody for 1-2 hr, rinsed, and then reincubated with secondary antibody for 1-2 hr. Stained sections were mounted in $90 \%$ glycerol with $0.1 \%$ p-phenylenediamine to retard fading.

Cultured cells on coverslips were fixed with $1 \%$ paraformaldehyde, 100 mM L-lysine, and $10 \mathrm{~mm} m$-periodate in PBS paraformaldehyde-lysineperiodate (PLP) for $10 \mathrm{~min}$ at room temperature. For permeabilization, cells were fixed with PLP plus $0.1 \%$ saponin, incubated with $1 \%$ Triton X-100 in PBS for 10 min, blocked with $2 \%$ BSA and $10 \%$ normal goat serum in PBS, and stained as above.

\section{RESULTS}

\section{AChR clusters at synaptic sites in mouse sympathetic ganglion}

In muscle, nicotinic AChRs form high-density clusters in the postsynaptic membrane precisely beneath motor nerve terminals. Clustering of neuronal nicotinic AChRs has also been documented in chick and frog sympathetic ganglia (Jacob and Berg, 1983; Loring and Zigmond, 1987; Sargent and Pang, 1989; Horch and Sargent, 1995, 1996; Wilson and Sargent, 1996) but not, to our knowledge, in mammalian neurons. Accordingly, we began the present study by assessing the distribution of AChRs in mouse SCG.

Molecular and electrophysiological studies have provided evidence that rodent SCG expresses the neuronal AChR $\alpha 3, \alpha 4, \alpha 5$, $\alpha 7, \beta 2$, and $\beta 4$ subunits (Mandelzys et al., 1994, 1995; Rust et al., 1994; McGehee and Role, 1995; Zoli et al., 1995). We stained sections of mouse SCG with a panel of antibodies to these subunits (see Materials and Methods). Two antibodies, mAb 210 and $\mathrm{mAb} 270$, stained small patches in the neuropil (Fig. 1a,b). The patches were approximately circular, had sharp borders, were $\sim 0.2-1.0 \mu \mathrm{m}$ in diameter, and were not stained when control antibodies or preimmune sera were substituted for anti-AChR (data not shown). mAb 270 recognizes the AChR $\beta 2$ subunit in several species, and mAb 210 recognizes both $\alpha 3$ and $\alpha 5$ subunits of chicken and human AChR (Lindstrom, 1996). However, the epitope to which it binds is not conserved in the rodent $\alpha 3$ subunit (Boulter et al., 1986; Lindstrom, 1996), and mAb 210 did not recognize recombinant rat $\alpha 3$ (see below). In mouse SCG, therefore, it probably recognizes only the $\alpha 5$ subunit. Consistent with 

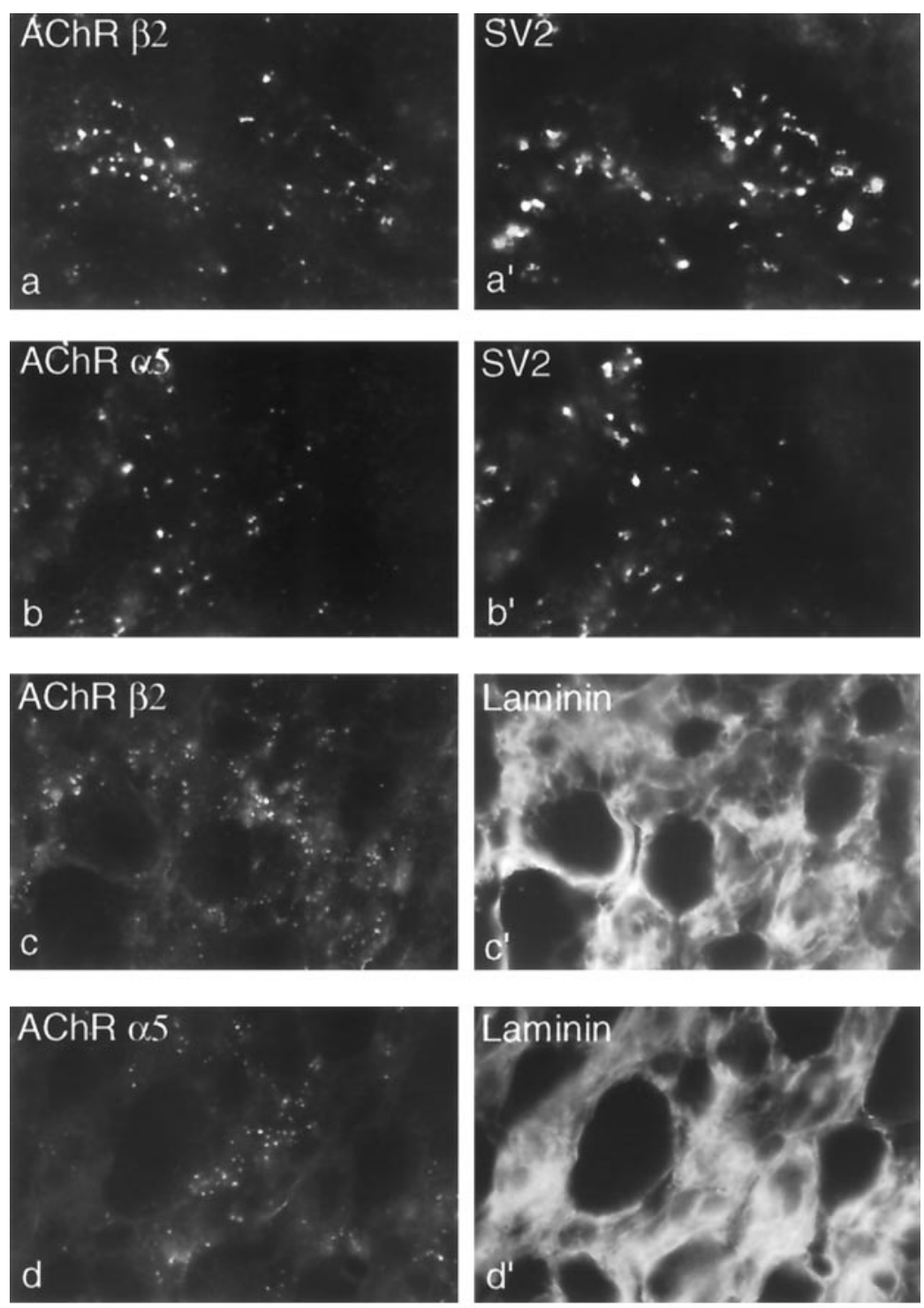

Figure 1. Distribution of AChRs in mouse SCG. Sections of P23-P25 SCG were double-stained with antibodies to neuronal AChR subunits $(a-e)$ plus anti-SV2 $\left(a^{\prime}, b^{\prime}, e^{\prime}\right)$ or anti-laminin $\left(c^{\prime}, d^{\prime}\right)$. Both anti-AChR $\beta 2(\mathrm{mAb} 270 ; a, c, e)$ and anti-AChR $\alpha 5$ (mAb 210; $b, d)$ stained small discrete patches, most of which were associated with nerve terminals $\left(a^{\prime}, b^{\prime}\right)$ and were clustered in the neuropil rather than on the surface of somata $\left(c^{\prime}, d^{\prime}\right)$. The section in $e$ and $e^{\prime}$ was from a ganglion that had been denervated 3 d earlier; SV2-positive nerve terminals had degenerated but $\mathrm{AChR}$ clusters persisted, demonstrating that most, if not all, AChRs are postsynaptic. Scale bar (in $\left.e^{\prime}\right): a, b$, $10 \mu \mathrm{m} ; c-e, 20 \mu \mathrm{m}$.
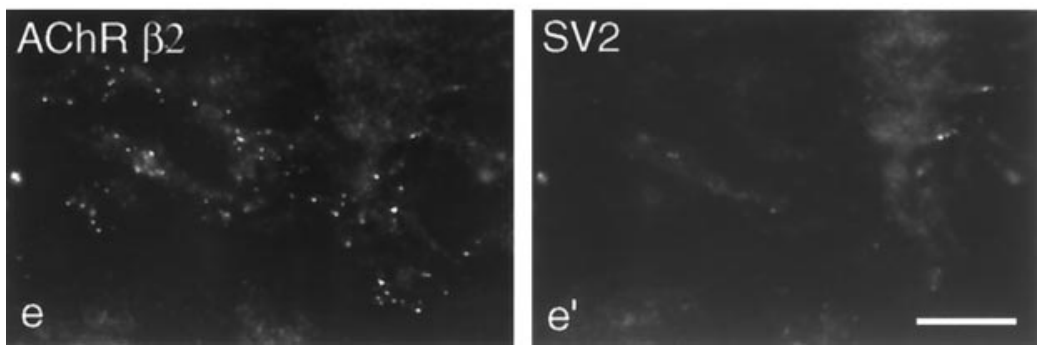

the finding that ganglionic neurons bear AChRs of subunit composition $\alpha 3 \beta 2$ and $\alpha 3 \alpha 5 \beta 2$ (Mandelzys et al., 1995), staining by mAb 210 and mAb 270 was qualitatively similar but more intense with the latter.

To assess the spatial relationship of the AChR clusters to ganglion cells and nerve terminals, we performed a series of double-labeling experiments. First, we used an antibody to a synaptic vesicle protein, SV2, to mark presynaptic boutons. At least two-thirds of the mAb 270- and mAb 210-reactive puncta were directly apposed to SV2-rich boutons (Fig. $1 a^{\prime}, b^{\prime}$ ). Therefore, the majority of AChR clusters in adult SCG are synaptic. On the other hand, some SV2-positive terminals were unac- companied by mAb 270- or mAb 210-positive puncta; this may result either from glancing sections or from the predominance of other AChR subunits (e.g., $\alpha 3$ or $\beta 4$ ) at some synapses. Second, we stained for laminin, a component of the basal laminae that surround Schwann and satellite cells, which in turn ensheathe somata and processes (Fig. $1 c^{\prime}, d^{\prime}$ ). Doublelabeling with anti-laminin plus either mAb 270 or mAb 210 showed that most AChR-rich puncta were located in processrich regions, presumably dendritic bundles, rather than on somata (Fig. 1c,d). Finally, we stained for NCAM, a neuronal adhesion molecule widely expressed in neuronal processes and cell-cell contacts. Again, double labeling showed that the 
a

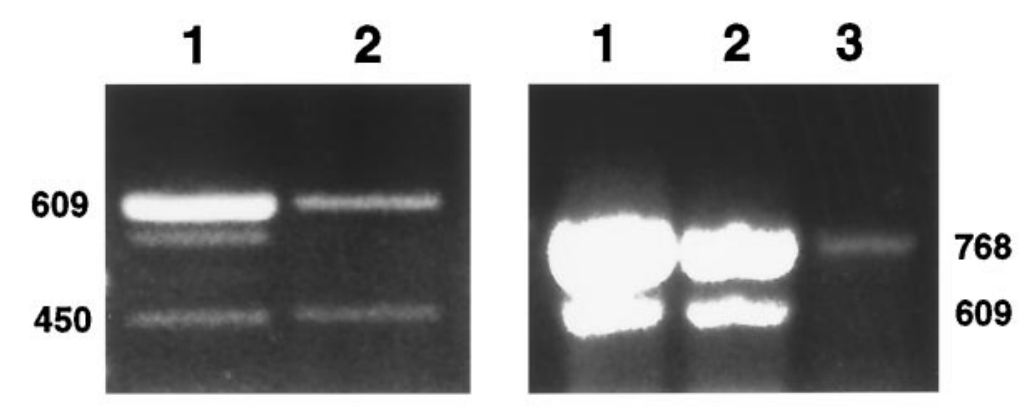

C

TCLGLPGTRA GAQLGGQVSL SMGNAFLGLS LFQKALESFE KALRYAHNN FCLGLPGTRA GAQLGGQVSL SMGNAFLGLS LFQKALESFE KALRYAHNND

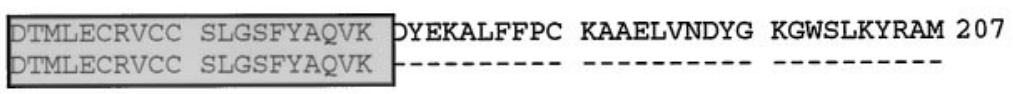

SQYHMAVAYR LLGHLGSAME CCE ESMKIAL QHGDRPLQAL CLLCFADIHR 257 -

d
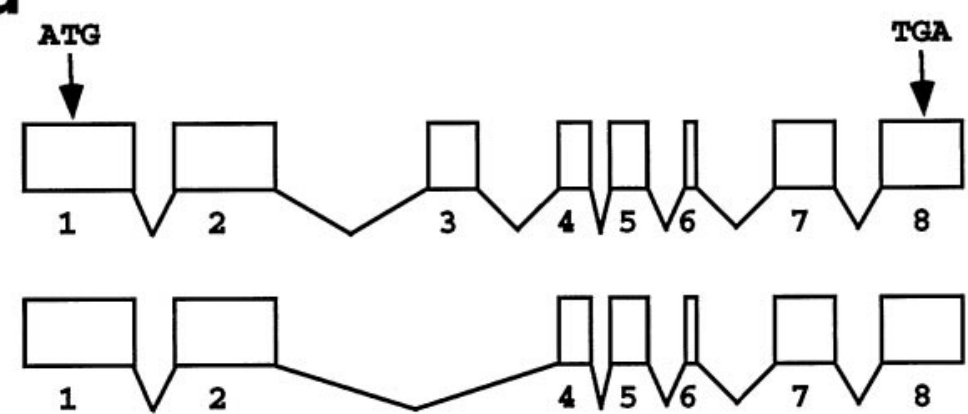

Figure 2. Detection and characterization of rapsyn RNA. $a$, RT-PCR of total RNA from muscle (lane 1) and SCG (lane 2), using rapsyn-specific primers. A band of the predicted size of $609 \mathrm{nt}$ was readily amplified from both samples but was more abundant in muscle than in SCG. A band of $450 \mathrm{nt}$ was also detected in both samples but was a larger fraction of the total product in SCG. $b$, RT-PCR of poly $\left(\mathrm{A}^{+}\right)$RNA from muscle (lane 1), PC12 cells (lane 2), and brain (lane 3) using a second set of rapsyn-specific primers designed to amplify a $768 \mathrm{nt}$ segment. Low levels of rapsyn RNA were detected in the brain sample, and relatively high levels were detected in PC1 2 cells. As in $a$, a band $\sim 150 \mathrm{nt}$ smaller than the predicted band was also amplified. $c$, Part of the sequence of the $450 \mathrm{nt}$ band from $a$, lane 2 (bottom line), aligned with sequence of full-length rapsyn (top line). The shorter band encodes a protein that lacks a 53-amino acid segment. $d$, The short form of rapsyn is likely to be generated from an alternatively spliced mRNA that lacks exon 3. Top, structure of the rapsyn gene, from Gautam et al. (1994). Bottom, The alternatively spliced RNA that encodes the short form. majority of mAb 270- and mAb 210-positive puncta were in process-rich regions (data not shown).

In the brain, many AChRs are presynaptic (Swanson et al., 1987; Role and Berg, 1996). Although double labeling with antiSV2 and anti-AChR showed that ganglionic receptors were synapse-associated, this method was unable to distinguish presynaptic from postsynaptic sites. To distinguish these alternatives, we denervated the SCG in adult mice by cutting the cervical sympathetic trunk, waited $3 \mathrm{~d}$ for preganglionic terminals to degenerate, and then double stained with mAb 270 and anti-SV2. Although SV2 staining was nearly eliminated after denervation (Fig. 1e'), mAb 270-positive clusters persisted (Fig. 1e). Thus, $\beta 2$-containing AChRs in SCG are predominantly postsynaptic.

\section{Expression of rapsyn in sympathetic neurons}

Using reverse transcription-PCR (RT-PCR), we readily detected rapsyn RNA in samples of total RNA prepared from SCG (Fig. $2 a$ ). Transcript was also detected in brain, consistent with a recent report by Yang et al. (1997). However, levels were extremely low compared with those in muscle and SCG, and detection required use of poly $\left(\mathrm{A}^{+}\right)$RNA as template (Fig. $2 b$ ). Because most syn- apses in SCG, but only a small fraction of synapses in the brain, are cholinergic, this result supports the notion that rapsyn interacts selectively with neuronal AChRs at cholinergic synapses.

To ask whether rapsyn is expressed by neurons, we turned to the PC12 cell line. These cells were derived from a pheochromocytoma but stop dividing and acquire numerous features of sympathetic neurons when treated with NGF (Greene and Tischler, 1976). The abundance of rapsyn RNA was at least as high in NGF-treated PC12 cells as in sympathetic ganglia (Fig. 2b) (data not shown). Thus, sympathetic neuron-like cells and, by implication, sympathetic neurons express rapsyn.

We attempted to detect additional genes related to rapsyn using degenerate PCR with a variety of primers but obtained no evidence for homologs. Likewise, no vertebrate rapsyn-like sequences other than rapsyn itself were present in public databases as of March 1998. However, RT-PCR with both degenerate and specific primers generated an additional product $\sim 150 \mathrm{bp}$ smaller than the predicted size. With the primers used in Figure $2 a$, for example, the known sequence predicted a product of $609 \mathrm{bp}$, but products of $\sim 600$ and $\sim 450$ bp were detected. Likewise, the 
Muscle
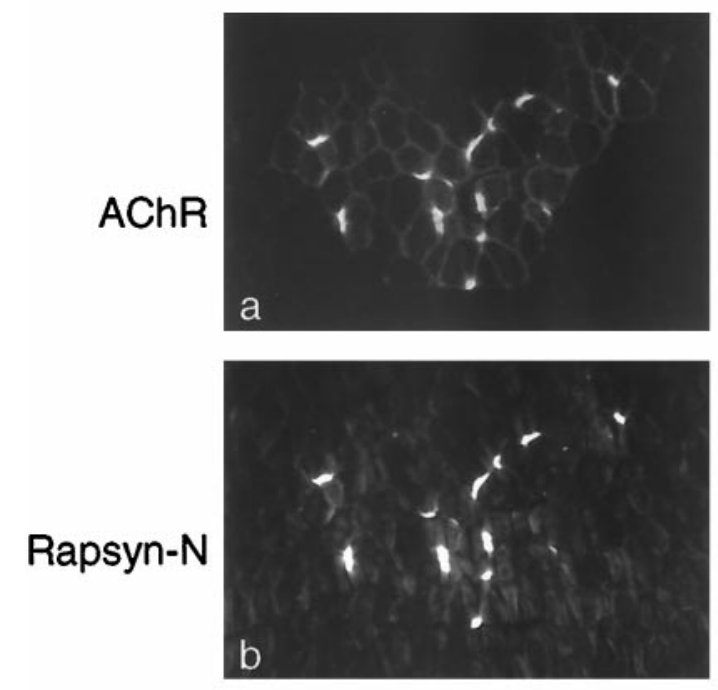

Figure 3. Rapsyn protein is undetectable at AChR clusters in SCG. Sections of mouse skeletal muscle $(a-c)$ or SCG $(d-f)$ were labeled with $\mathrm{mAb} 210$, which recognizes the muscle AChR $\alpha$ subunit and the neuronal AChR $\alpha 5$ subunit $(a, d)$, plus either polyclonal antibodies to the $\mathrm{N}$ terminus of rapsyn $(b, e)$ or a monoclonal antibody to the $\mathrm{C}$ terminus of rapsyn ( $c$, $f$ ). Concentrations were adjusted so that staining was more intense by anti-rapsyn than by anti-AChR in muscle. Although muscle and SCG were stained under identical conditions, no staining by anti-rapsyn was detectable in SCG. Thus, if rapsyn is present at synaptic sites in SCG, it is not present at the 1:1 ratio with AChRs found in muscle. Because mAb 210 stains all AChRs in muscle but only a subset of AChRs in SCG, the difference in the AChR/ rapsyn ratio between the two tissues is even greater than it appears to be in these micrographs. Scale bar (in $f$ ): $a-c, 50 \mu \mathrm{m} ; d-f, 6 \mu \mathrm{m}$.

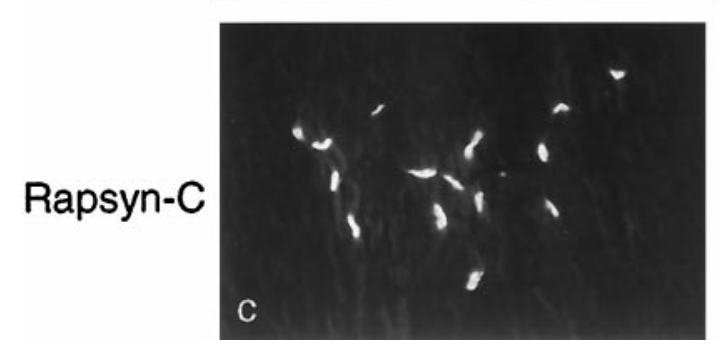

primers used in Figure $2 b$ generated not only the predicted $768 \mathrm{bp}$ band but also a band of $\sim 600 \mathrm{bp}$. Although we did not quantitate the levels of the two products, the smaller product was nearly as abundant as the larger product in RNA from SCG or PC12 cells but much less abundant in muscle RNA. We therefore cloned the smaller product. Sequencing of 12 independent clones revealed a single product that was identical to rapsyn at both ends and was therefore derived from the rapsyn gene (Fig. $2 c$ ). Its short size reflected the deletion of a single block of $159 \mathrm{nt}$ from the fulllength RNA. Analysis of genomic structure (Gautam et al., 1994) indicated that the deleted sequences corresponded exactly to exon 3 of the rapsyn gene (Fig. $2 d$ ). Deletion of this exon maintains the open reading frame. Thus, it is likely that the rapsyn gene is alternatively spliced and that alternative splicing is subject to tissue-specific regulation.

Although rapsyn RNA was readily detectable in SCG and PC12 cells, we were unable to detect the cognate protein using either monoclonal or affinity-purified polyclonal antibodies to rapsyn. Both antibodies stained skeletal neuromuscular junctions intensely (Fig. 3b,c), and both recognized epitopes outside of the segment deleted in the short rapsyn isoform (see below). However, no signal above background was detectable in sections of adult or neonatal SCG stained with either antibody (Fig. 3e,f). Moreover, neither antibody stained PC12 cells detectably (data not shown). One possible explanation for this failure is that AChRs are less densely clustered at ganglionic than at neuromuscular synapses; if rapsyn were equimolar with AChR in ganglia as it is at neuromuscular junctions (LaRochelle and Froehner, 1986), then it might be difficult to detect in the former. To test this possibility, we used conditions in which (1) anti-rapsyn fluorescence was as bright as anti-AChR fluorescence in muscle, and (2)
AChR clusters were clearly detectable in both muscle and ganglia. Even when both tissues were stained in parallel under these conditions, no rapsyn was detectable in ganglia (Fig. 3). Thus, even if rapsyn is present in SCG, the mole ratio of rapsyn/AChR is far lower at ganglionic synapses than at neuromuscular junctions.

\section{Interaction of rapsyn and AChRs in heterologous cells}

The ability of rapsyn to cluster muscle AChRs was initially demonstrated by coexpression in heterologous cells (Froehner et al., 1990; Phillips et al., 1991a). Here, we used QT-6 fibroblasts to test whether rapsyn interacts with neuronal AChRs. A major advantage of this cell type is that transfection efficiency is routinely $>50 \%$.

First, we transfected QT-6 cells with expression vectors encoding AChR subunits and then stained nonpermeabilized cells with subunit-specific antibodies to AChRs. When only a single subunit ( $\alpha 4$ or $\beta 2$ ) was transfected, no staining was visible on the surface of the transfected cells (Fig. 4a) (data not shown). In contrast, cotransfection of $\beta 2$ with either $\alpha 3$ or $\alpha 4$ resulted in significant surface expression of receptors (Fig. $4 b, c$ ). To test the possibility that failure to detect surface-associated single subunits reflected failure of expression, we stained permeabilized cells and showed that single subunits and pairs of subunits were expressed at similar levels (Fig. 4e-g). Thus, consistent with results from biochemical studies (Wang et al., 1996), these data suggest that assembly of appropriate multimers is necessary for the surface appearance of neuronal AChRs.

Next, we cotransfected neuronal AChR subunits ( $\alpha 4$ or $\beta 2$ ) or pairs of subunits ( $\alpha 3$ plus $\beta 2$ or $\alpha 4$ plus $\beta 2$ ) with rapsyn and then stained unpermeabilized cells to assess the distribution of surface 

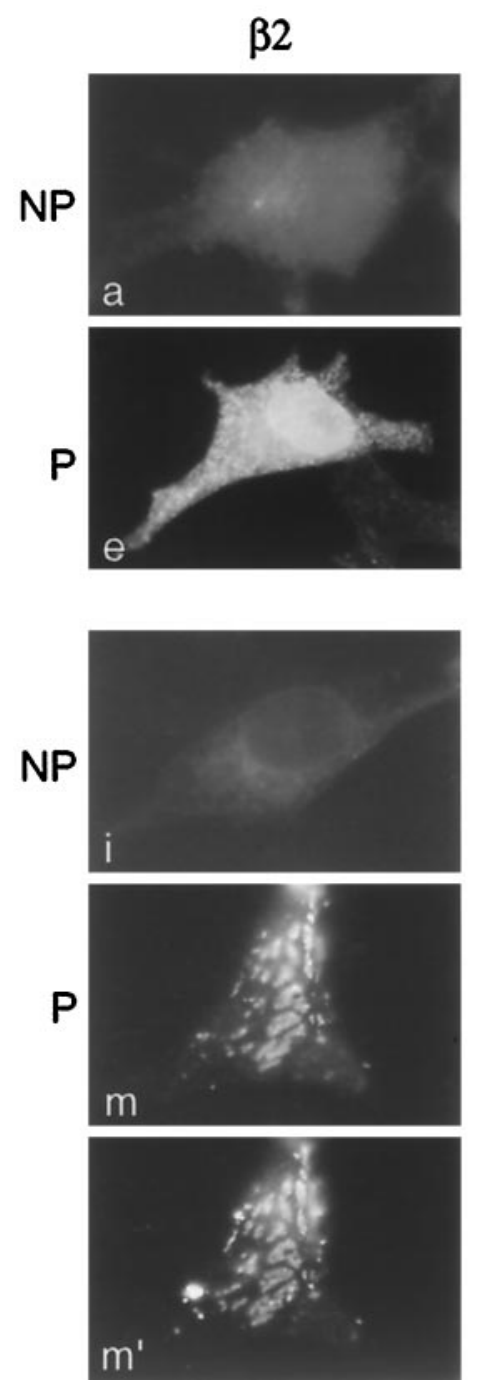
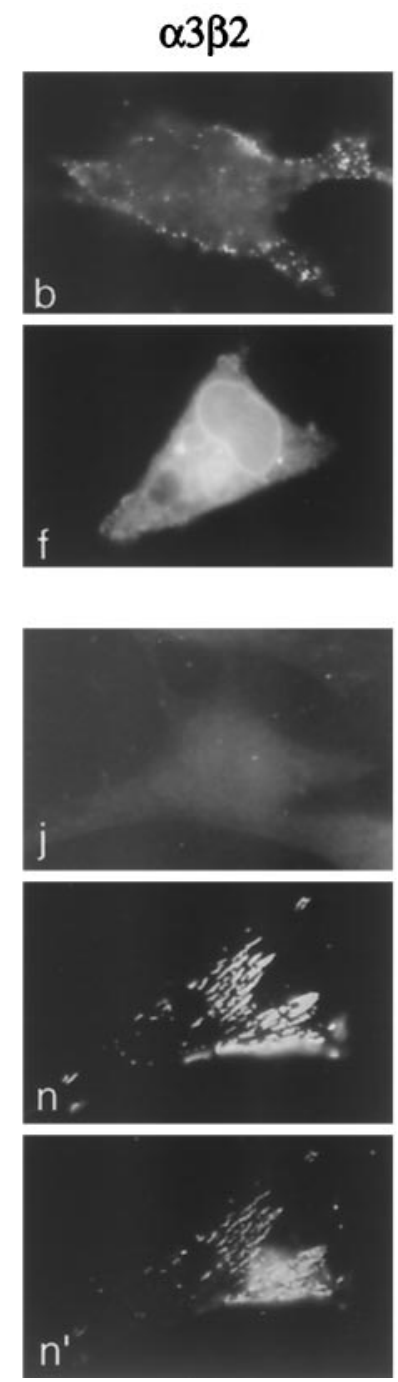
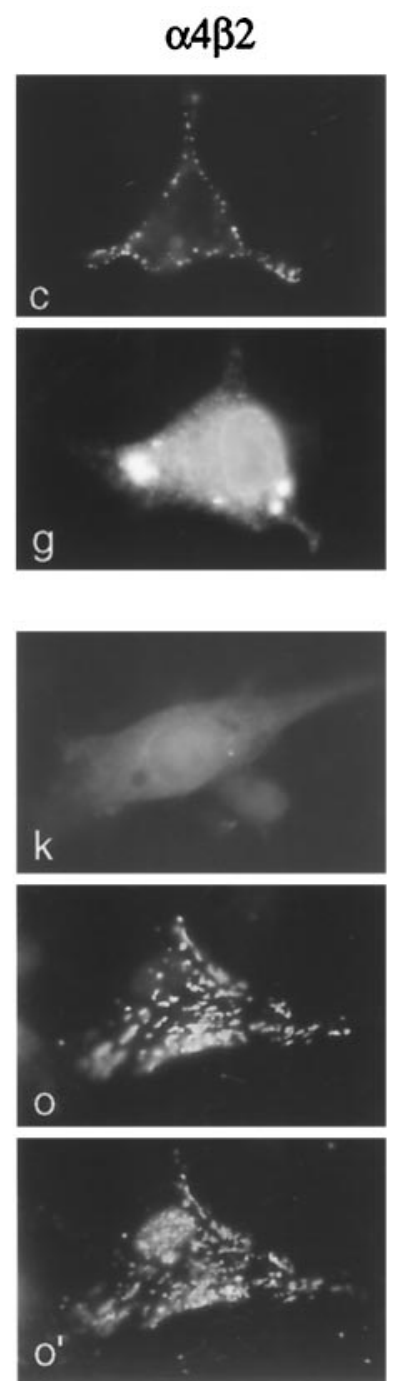
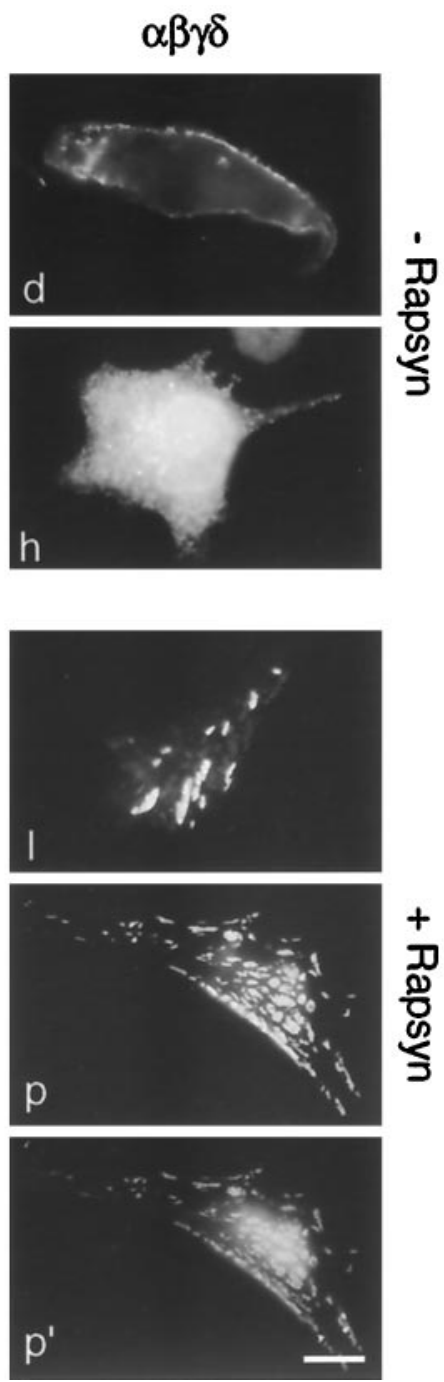

Figure 4. Rapsyn-induced clustering of AChRs in transiently transfected cells. QT-6 cells were transfected with expression vectors encoding the AChR $\beta 2(a, e, i, m), \alpha 3$ plus $\beta 2(b, f, j, n), \alpha 4$ plus $\beta 2(c, g, k, o)$, or $\alpha$ plus $\beta$ plus $\gamma$ plus $\delta(d, h, l, p)$ subunits, either without $(a-h)$ or with $(i-p)$ an expression vector encoding mouse rapsyn. Two days later, the cultures were stained with antibodies to the AChR $\beta 2(a-c, e-g, i-k, m-o)$ or $\alpha$ subunit $(d, h, l, p)$, either without $(N P)$ or after permeabilization $(P)$ to reveal cell surface or all AChRs, respectively. Cultures in $m-p$ were double-stained with anti-rapsyn $\left(m^{\prime}-p^{\prime}\right)$. Rapsyn induces clustering of muscle and neuronal receptors, but clusters of neuronal AChRs are retained intracellularly. Scale bar, $10 \mu \mathrm{m}$.

AChRs. No AChR clusters appeared on the surface of the cotransfected cells. Instead, levels of surface AChRs were lower in the presence of rapsyn than in their absence (Fig. 4i-k). Surprisingly, however, when cells were permeabilized before staining, clusters of AChRs were readily detectable in $\sim 50 \%$ of all cells (Fig. $4 m-o$ ), and these clusters were precisely colocalized with high-density aggregates of rapsyn (Fig. $4 m^{\prime}-o^{\prime}$ ). Thus, although rapsyn can interact with neuronal AChRs, rapsyn-induced aggregates are trapped intracellularly.

These results differed greatly from those previously reported for rapsyn-clustered muscle AChRs that reach the cell surface in heterologous cells (Froehner et al., 1990; Phillips et al., 1991a; Brennan et al., 1992; Maimone and Merlie, 1993; Ramarao and Cohen, 1997) as they do in muscle. We therefore repeated the transfections in QT-6 cells using expression vectors encoding the muscle $\alpha, \beta, \gamma$, and $\delta$ AChR subunits. As expected, muscle AChRs were diff usely distributed on the surface of QT-6 cells in the absence of rapsyn (Fig. $4 d$ ) and formed high-density surface clusters in the presence of rapsyn (Fig. $4 l$ ). It appeared that some rapsyn-induced muscle AChR clusters remained intracellular because there were generally more clusters per cell and more cluster-bearing cells in cultures stained after permeabilization than in cultures stained without permeabilization (Fig. 4l,p). Nonetheless, the difference in behavior between muscle and neuronal AChRs was qualitative and clear-cut; numerous rapsyninduced clusters of muscle AChRs appeared on the cell surface, whereas rapsyn-induced clusters of neuronal AChRs were always intracellular.

As an additional control, we expressed rapsyn in a clone of HEK293 cells that had been stably transfected with the AChR $\alpha 4$ and $\beta 2$ subunits. Ramarao and Cohen (1997) have shown that muscle AChRs expressed alone are diffusely distributed on the surface of these cells, whereas cotransfection with rapsyn leads to formation of AChR clusters on the cell surface. In the $\alpha 4$ plus $\beta 2$-expressing cell line, functional receptors were detectable on the cell surface by electrophysiological methods (data not shown), and antibodies to either the $\alpha 4$ or $\beta 2$ subunits stained the cell surface diffusely (Fig. 5a,b). As in QT-6 cells, expression of 

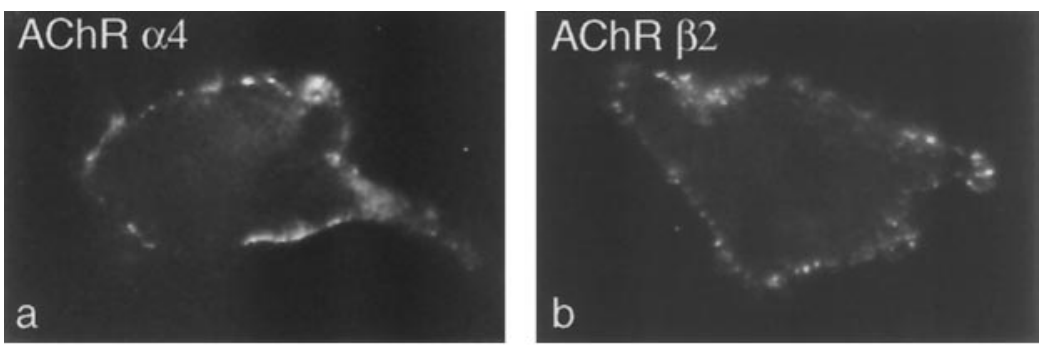

Figure 5. Rapsyn-induced clustering of AChRs in stably transfected human cells. HEK 293 cells stably transfected with AChR $\alpha 4$ plus $\beta 2$ expression vectors were stained with antibodies to $\alpha 4(a)$ or $\beta 2(b)$. AChRs were diffusely distributed on the cell surface. Sister cultures were transiently transfected with rapsyn and then permeabilized and doublestained with anti- $\beta 2(c)$ and anti-rapsyn $\left(c^{\prime}\right)$. Rapsyn induced clustering of AChRs. No clusters were detected in nonpermeabilized cells (data not shown), indicating that in HEK 293 cells as in QT-6 cells, clusters of neuronal AChRs are retained intracellularly. Scale bar, $10 \mu \mathrm{m}$.
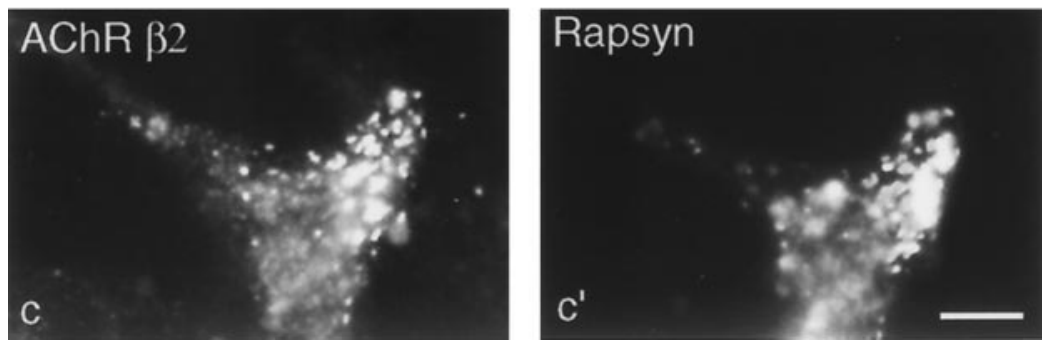

rapsyn along with $\alpha 4$ plus $\beta 2$ led to formation of intracellular AChR-rapsyn aggregates but not to surface-associated aggregates (Fig. $5 c, c^{\prime}$ ) (data not shown). Thus, the differing ability of rapsyn to cluster surface-associated muscle and neuronal AChRs is not peculiar to avian cells (because HEK 293 cells are of human origin), to fibroblasts (because HEK 293 cells are epithelial), or to transiently expressed AChRs.

Finally, we considered the possibility that the short form of rapsyn found in SCG might interact with neuronal AChRs. This seemed plausible because the deletion of exon 3 (Fig. 2) leaves intact both $\mathrm{N}$-terminal sequences necessary for self-aggregation of rapsyn and C-terminal sequences necessary for interaction of rapsyn with muscle AChRs in HEK293 cells (Ramarao and Cohen, 1997). We therefore constructed an expression vector that encoded the short form and tested it in QT-6 cells. Unlike the full-length rapsyn, the short-rapsyn isoform did not form aggregates on its own and did not induce surface-associated or intracellular clusters of either muscle $(\alpha \beta \gamma \delta)$ or neuronal ( $\alpha 3$ plus $\beta 2$ or $\alpha 4$ plus $\beta 2$ ) AChRs (Fig. 6).

\section{Clustering of ganglionic AChRs in the absence of rapsyn}

As a genetic test of whether neuronal AChR clustering requires rapsyn, we examined SCG from rapsyn-deficient mutant mice. Because homozygous rapsyn mutant mice die at postnatal day 0 (P0) (Gautam et al., 1995), we first stained SCG from control neonates with mAb 210 and mAb 270, which revealed $\alpha 5$ - and $\beta 2$-containing AChR clusters in older mice (see above). AChR clusters were present by $\mathrm{P} 0$, although they were both fewer in number and smaller in size than those seen at P20 (compare Figs. 1, 7a,c). Moreover, double staining with SV2 revealed that many AChR clusters were not apposed to SV2-positive nerve terminals at P0 (Fig. $7 a^{\prime}, c^{\prime}$ ).

Qualitatively AChR clusters in rapsyn ${ }^{-1-}$ SCG resembled those in littermate controls. Clusters were stained by mAb 210 and $\mathrm{mAb} 270$, indicating that both $\alpha 5$ - and $\beta 2$-containing AChRs were present (Fig. $7 b, d$ ). Double staining with anti-SV2 showed that synaptic and extrasynaptic clusters were present in mutants (Fig. $7 b^{\prime}, d^{\prime}$ ). Neither the intensity of staining nor the size of clusters differed noticeably between mutant homozygotes and littermates. We also counted mAb 210- and mAb 270-positive clusters in sections. As shown in Figure $7 e$, the number of mAb 210- and mAb 270-positive clusters was similar in mutants and controls. Thus, rapsyn does not greatly affect the size, location, density, or number of AChR clusters in the SCG.

\section{Gephyrin in SCG}

AChR subunits are distantly related to subunits of glycine and $\mathrm{GABA}_{\mathrm{A}}$ receptors. The cytoplasmic protein gephyrin has been implicated in clustering of these receptors (Kirsch et al., 1995, 1996). Recently, Yang et al. (1997) showed that rapsyn, which has no significant homology to gephyrin, can cluster $\mathrm{GABA}_{\mathrm{A}}$ receptors in QT-6 cells. In light of these results, the persistence of neuronal AChR clustering in rapsyn ${ }^{-/-}$mice raised the possibility that gephyrin might be involved in clustering ganglionic AChRs. We therefore used a well characterized monoclonal antibody (Kirsch and Betz, 1993; Kirsch et al., 1995) to assess the distribution of gephyrin in SCG. As previously described, this antibody stains synapse-like puncta in the brain (Fig. 8a). However, we detected no significant staining in embryonic day 18 (E18) SCG of mutant or control mice (Fig. 8b,c), nor did we detect any signal in adult SCG (data not shown).

\section{DISCUSSION}

We have initiated a study of interneuronal synaptogenesis in the mouse SCG. This preparation is advantageous for several reasons. First, the synapse made by autonomic preganglionic axons on ganglionic neurons is relatively accessible to molecular, physiological, and structural analyses. Second, it comprises the vast majority of all synapses in the ganglion, making it straightforward to correlate structural, functional, and molecular results. Third, the structure, function, and development of this synapse have been studied in detail, so a great deal of background information is available. Fourth, and perhaps most important, the ganglionic synapse resembles the best studied of all synapses, the skeletal neuromuscular junction, in several respects: (1) both are cholinergic; (2) autonomic preganglionic neurons are clonally and molecularly related to skeletal motoneurons (Leber et al., 1990; Tsuchida et al., 1994); and (3) the nicotinic AChRs of the SCGs are similar in sequence and biophysical properties to the AChRs of the neuromuscular junction (Lindstrom, 1996). Thus, knowledge derived from studies of the neuromuscular junction may be more directly applicable to synapses in the SCG than to the predominantly noncholinergic synapses of the brain. Finally, the choice of mouse permits us to make use of molecular genetic 
Anti-AChR
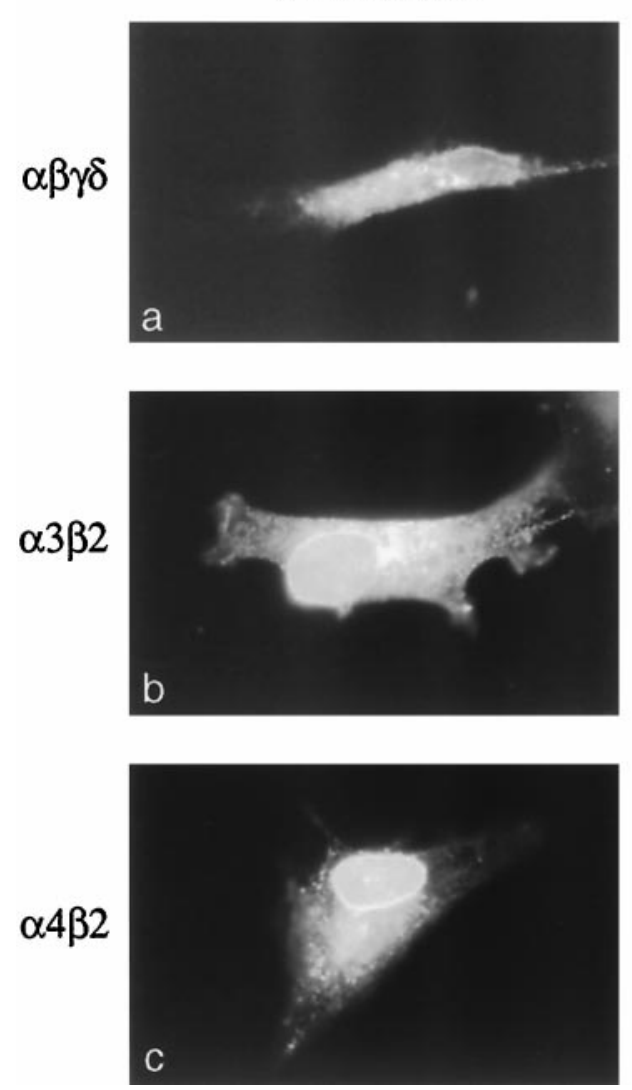

Anti-Rapsyn
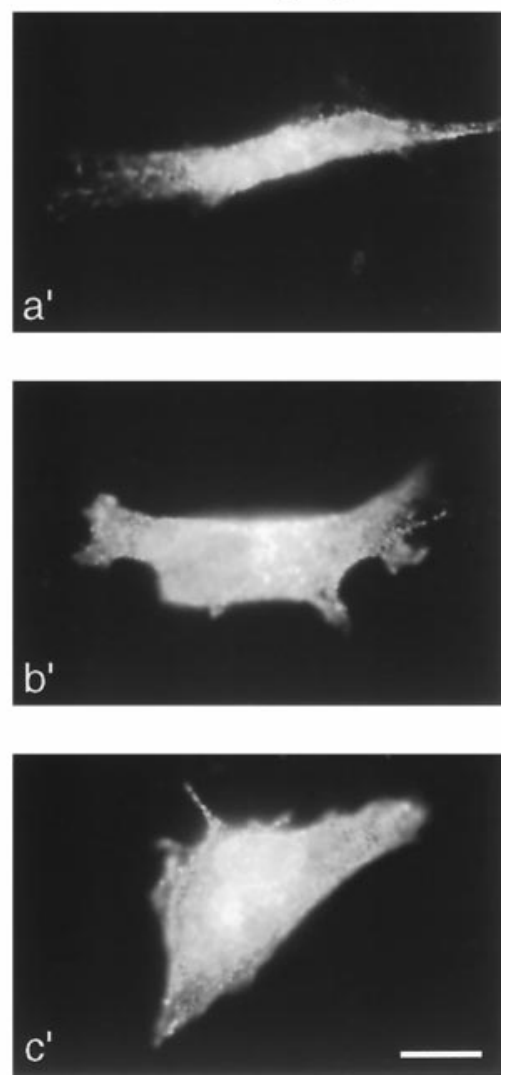

Figure 6. The short isoform of rapsyn cannot cluster AChRs. QT-6 cells were transiently transfected with an expression vector encoding the short form of rapsyn shown in Figure $2 c$, in addition to $\mathrm{AChR} \alpha$ plus $\beta$ plus $\gamma$ plus $\delta(a), \alpha 3$ plus $\beta 2(b)$, or $\alpha 4$ plus $\beta 2(c)$ subunits. Two days later, cells were permeabilized and stained with anti-AChR $(a-c)$ plus anti-rapsyn $\left(a^{\prime}-c^{\prime}\right)$. Antibodies to both the $\mathrm{C}$ terminus $\left(a^{\prime}-c^{\prime}\right)$ and $\mathrm{N}$ terminus (data not shown) (Fig. 3) recognized the short isoform. Both AChRs and the short form of rapsyn were diffusely distributed. Scale bar, $10 \mu \mathrm{m}$. approaches, beginning with the impressive number of mutant and transgenic strains already available (Sanes, 1997).

Here, we have focused on the clustering of neuronal nicotinic AChRs in the membrane of SCG neurons. Eleven neuronal nicotinic AChR subunits have been identified to date ( $\alpha 2-9$ and $\beta 2-4$; Lindstrom, 1996), of which at least six are expressed in rodent sympathetic ganglia: $\alpha 3-5, \alpha 7, \beta 2$, and $\beta 4$ (Rust et al., 1994; Zoli et al., 1995). Clusters of AChRs have been described in autonomic ganglia of frogs and chicks (Jacob and Berg, 1983; Loring and Zigmond, 1987; Sargent and Pang, 1989; Horch and Sargent, 1995, 1996; Wilson and Sargent, 1996), so we anticipated that at least some subunits would be clustered at synaptic sites in mouse SCG. Using monoclonal antibodies, we showed that $\alpha 5$ and $\beta 2$-containing AChRs are concentrated at postsynaptic sites in the mature SCG. Based on physiological studies, we expect that the ganglionic AChRs are heterogeneous and include pentamers in which $\alpha 3, \alpha 4$, and $\alpha 5$ subunits are combined with $\beta 2$ and/or $\beta 4$ (Mandelzys et al., 1994, 1995). Unfortunately, antibodies that reacted with mouse $\alpha 3, \alpha 4$, or $\beta 4$ subunits were not available to assess the full complement of ganglionic AChRs. (Note that the anti- $\alpha 4$ antibody used in Fig. 5 did not stain sections.) Our results also showed that some synaptic AChR clusters were present in perinatal SCG, consistent with earlier electrophysiological and electron microscopic studies (Smolen and Raisman, 1980; Rubin, 1985). Interestingly, some clusters were not obviously associated with nerve terminals at this stage. Additional studies will be required to determine whether nonsynaptic AChR clusters are eventually lost or whether they become innervated.

Having shown that synaptic AChR clusters are present in the SCG, we asked whether rapsyn was involved in clustering. As noted in the introductory remarks, rapsyn is both necessary and sufficient for clustering of AChRs at the neuromuscular junction. Rapsyn was originally thought to be restricted to muscle and electric organ, but lower levels of expression were reported in other tissues by Musil et al. (1989). Recently, Burns et al. (1997) and Yang et al. (1977) documented the presence of rapsyn RNA in avian ciliary ganglion and mouse brain, respectively, and suggested that rapsyn may be involved in neuronal synaptogenesis. Moreover, we found that rapsyn RNA was more abundant in the SCG than in brain as a whole, that a novel isoform of rapsyn RNA was selectively expressed in ganglia, and that rapsyn can induce clustering of neuronal AChRs in heterologous cells. However, three lines of evidence suggest that rapsyn is not, in fact, crucial for clustering of ganglionic AChRs.

First, although rapsyn RNA is readily detectable in SCG, we were unable to detect rapsyn protein in these ganglia. Initially, this was unsurprising; levels of rapsyn are low even in muscle, and AChR density is considerably lower at interneuronal than at neuromuscular synapses. Thus, low levels of ganglionic rapsyn might be difficult to detect. However, we were able to ask whether rapsyn and $\mathrm{AChRs}$ are present at a 1:1 ratio at synaptic sites in ganglia, as they are in muscle (LaRochelle and Froehner, 1986). To this end, we stained muscle and SCG under identical conditions, adjusted so that anti-rapsyn and anti-AChR generated equally bright signals in muscle. Under these conditions AChR clusters were clearly visible in the SCG, but rapsyn remained undetectable. From this result we conclude that if rapsyn is present at ganglionic synapses, it interacts with AChRs in a different way than it does in muscle.

Second, although rapsyn can aggregate both muscle and neuronal AChRs in heterologous cells, only muscle AChRcontaining clusters are transported to the plasma membrane. 

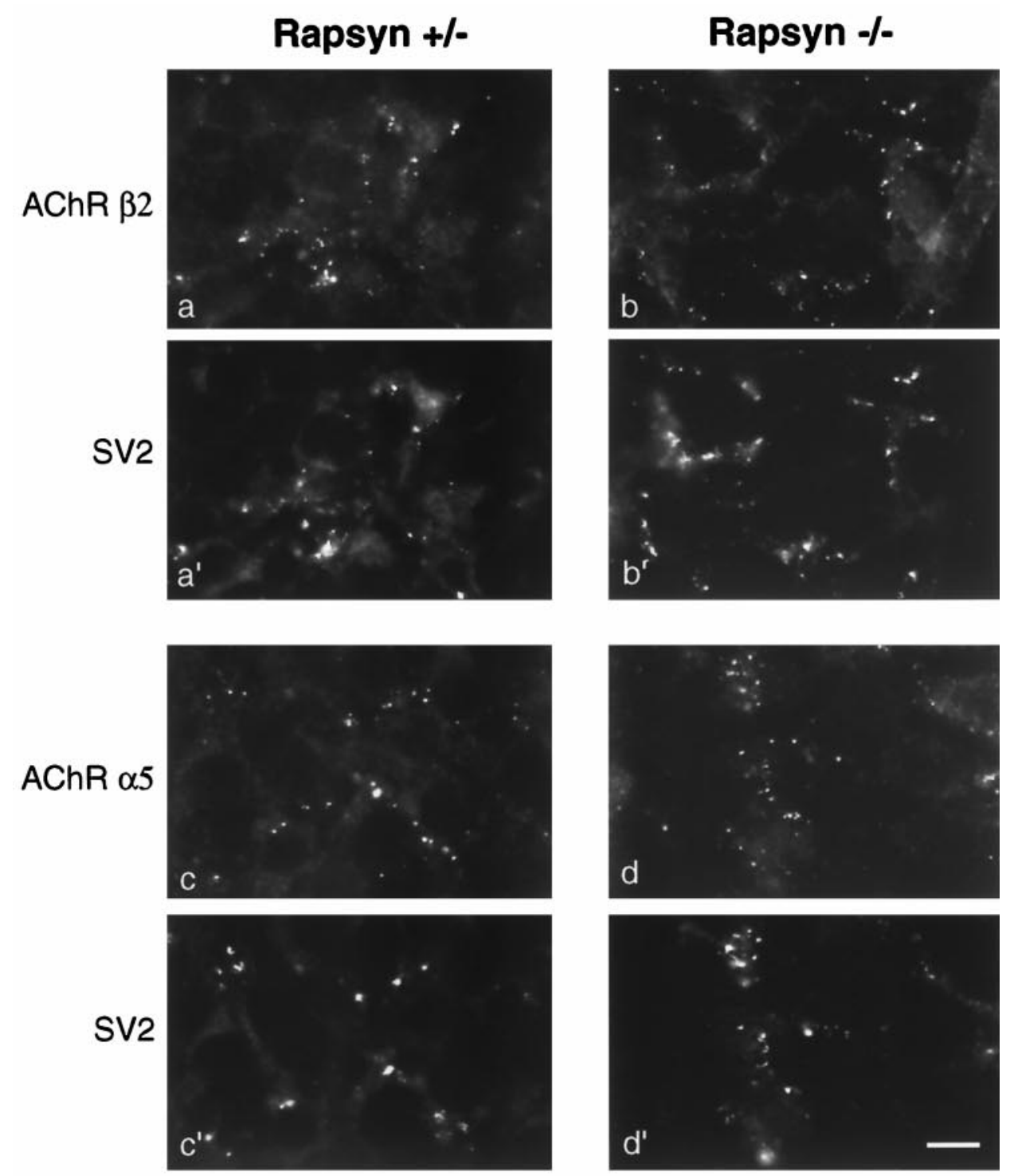

e

Figure 7. AChR clusters in SCG of rapsyn $^{-/-}$mice. Sections of SCG from E18 rapsyn $^{+/-}(a, c)$ or rapsyn ${ }^{-1-}(b, d)$ littermates were double-stained with anti-AChR $\beta 2(a, b)$ or $\alpha 5(c, d)$ plus anti-SV2 $\left(a^{\prime}-d^{\prime}\right)$. AChRs clusters were present at both synaptic and extrasynaptic sites in perinatal ganglia from both mutants and controls. $e$, Numbers of AChR-rich clusters in mutant and control ganglia. Scale bar, $10 \mu \mathrm{m}$.

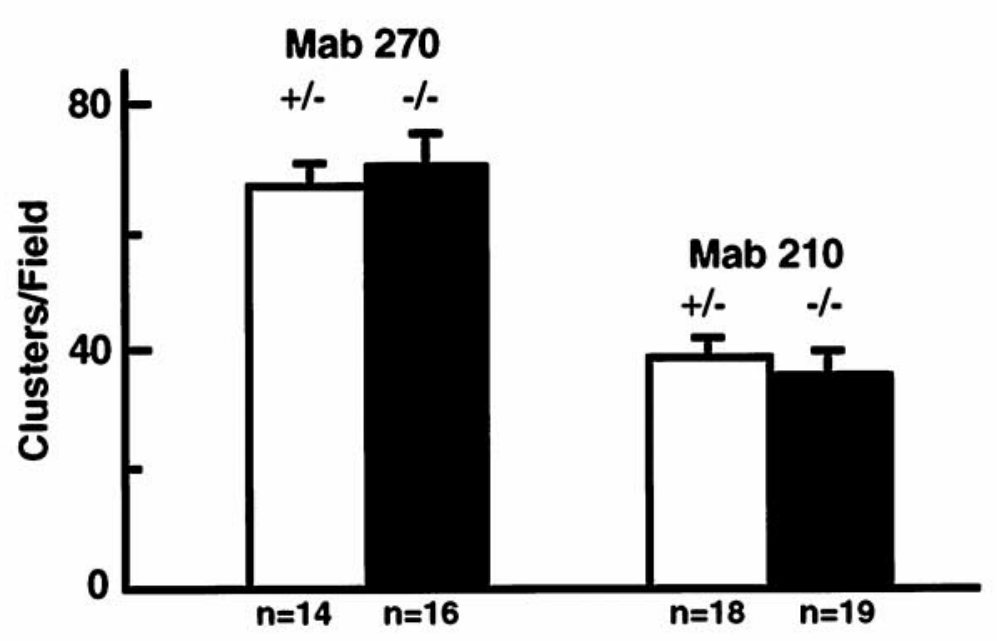



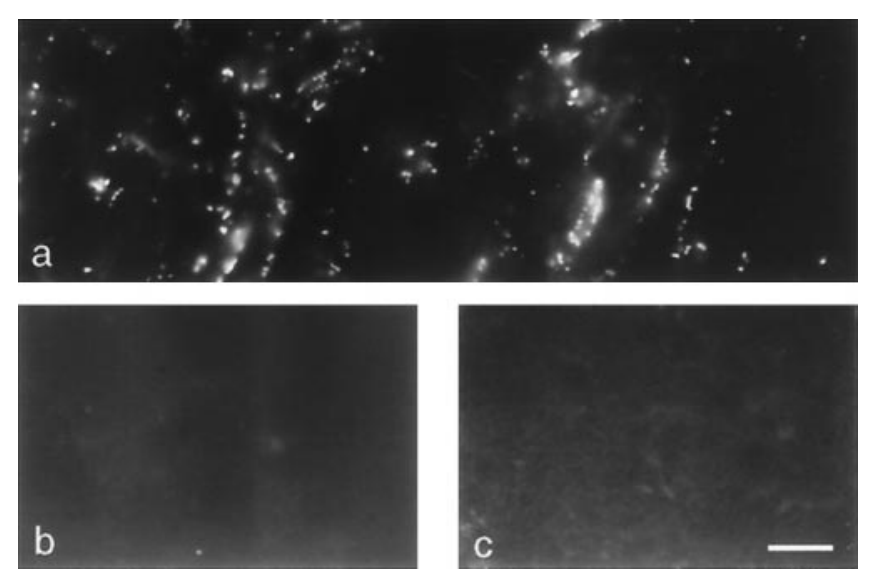

Figure 8. Immunostaining of gephyrin in brain and SCG. Sections of control adult brain $(a)$, control E18 SCG $(b)$, and rapsyn ${ }^{-1-}$ SCG $(c)$ were stained with anti-gephyrin. Gephyrin showed punctate staining in brain but no staining in SCG. Scale bar, $10 \mu \mathrm{m}$.

Several groups have demonstrated that rapsyn can cluster muscle AChRs in a variety of nonmuscle cells (Xenopus oocytes, Froehner et al., 1990; QT-6, Phillips et al., 1991a,b; COS cells, Brennan et al., 1992; HEK293 cells, Ramaroa and Cohen, 1997), and in each case, labeling of live cells has shown that at least some clusters reach the cell surface. Here, we have shown that rapsyn can cluster neuronal and muscle AChRs to a similar extent. In both QT-6 and HEK293 cells, however, the aggregates of neuronal AChRs are retained intracellularly. Thus, we suspect, but have not proven, that rapsyn interacts differently with muscle and neuronal AChRs, aggregating both but permitting only the former to reach the cell surface. Although the mechanistic basis for this difference awaits a better understanding of how rapsyn interacts with muscle AChRs, one possibility is that surface clustering of receptors by rapsyn involves two separable steps: aggregation with rapsyn intracellularly followed by export of the rapsyn-receptor complex to the cell surface. If this is so, then it might be that requirements for the second step (export) are more stringent than those for the first (aggregation), with both neuronal and muscle AChRs meeting the criteria for the first interaction but only muscle AChRs meeting the criteria for the second. Indeed, clustering and externalization have been shown to be separable processes for glycine and $\mathrm{GABA}_{\mathrm{A}}$ receptors (Kirch et al., 1995; Wan et al., 1997). In this light, it will be interesting to use chimeras between muscle and neuronal AChRs to dissect rapsyn-AChR interactions.

The final and most important piece of evidence that rapsyn is dispensable for neuronal AChR clustering came from the study of rapsyn-deficient mice. No AChR clusters have been detected in muscle of rapsyn ${ }^{-/-}$mice or in myotubes cultured from the mutants (Gautam et al., 1995; Apel et al., 1997). In contrast, neuronal AChR clusters are normal in size, shape, and number in rapsyn $^{-/-}$SCG. Because rapsyn ${ }^{-/-}$mice die within a few hours of birth, it remains possible that rapsyn plays a role in the maturation or maintenance of ganglionic synapses. However, it seems highly likely that other molecules, functional if not structural homologs of rapsyn, are required for the initial clustering of AChRs at ganglionic synapses. Recent discoveries of such molecules at glutamatergic and glycinergic synapses (see introductory remarks) suggest strategies for seeking their counterparts in the SCG.

\section{REFERENCES}

Apel ED, Roberds SL, Campbell KP, Merlie JP (1995) Rapsyn may function as a link between the acetylcholine receptor and the agrinbinding dystrophin-associated glycoprotein complex. Neuron 15:115-126.

Apel ED, Glass DJ, Moscoso LM, Yancopoulos GD, Sanes JR (1997) Rapsyn is required for MuSK signaling and recruits synaptic components to a MuSK-containing scaffold. Neuron 18:623-635.

Boulter J, Evans K, Goldman D, Martin G, Treco D, Heinemann S, Patrick J (1986) Isolation of a cDNA clone coding for a possible neural nicotinic acetylcholine receptor alpha-subunit. Nature 319:368-374.

Brakeman PR, Lanahan AA, O'Brien R, Roche K, Barnes CA, Huganir RL, Worley PF (1997) Homer: a protein that selectively binds metabotropic glutamate receptors. Nature 386:284-288.

Brennan C, Scotland PB, Froehner SC, Henderson LP (1992) Functional properties of acetylcholine receptors coexpressed with the $43 \mathrm{~K}$ protein in heterologous cell systems. Dev Biol 149:100-111.

Buckley K, Kelly RB (1985) Identification of a transmembrane glycoprotein specific for secretory vesicles of neural and endocrine cells. J Cell Biol 100:1284-1294.

Burns AL, Benson D, Howard MJ, Margiotta JF (1997) Chick ciliary ganglion neurons contain transcripts coding for acetylcholine receptorassociated protein at synapses (rapsyn). J Neurosci 17:5016-5026.

Chen C, Okayama H (1987) High-efficiency transformation of mammalian cells by plasmid DNA. Mol Cell Biol 7:2745-2752.

Chen Q, Fletcher GH, Steinbach JH (1995) Selection of stably transfected cells expressing a high level of fetal muscle nicotinic receptors. J Neurosci Res 40:606-612.

Cho KO, Hunt CA, Kennedy MB (1992) The rat brain postsynaptic density fraction contains a homolog of the Drosophila discs-large tumor suppressor protein. Neuron 9:929-942.

Chomczynski P, Sacchi N (1987) Single-step method of RNA isolation by acid guanidinium thiocyanate-phenol-chloroform extraction. Anal Biochem 162:156-159.

Deneris ES, Connolly J, Boulter J, Wada E, Wada K, Swanson LW, Patrick J, Heinemann S (1988) Primary structure and expression of beta 2: a novel subunit of neuronal nicotinic acetylcholine receptors. Neuron 1:45-54.

Dong H, O'Brien RJ, Fung ET, Lanahan AA, Worley PF, Huganir RL (1997) GRIP: a synaptic PDZ domain-containing protein that interacts with AMPA receptors. Nature 386:279-284.

Froehner SC, Gulbrandsen V, Hyman C, Jeng AY, Neubig RR, Cohen JB (1981) Immunofluorescence localization at the mammalian neuromuscular junction of the Mr 43,000 protein of Torpedo postsynaptic membranes. Proc Natl Acad Sci USA 78:5230-5234.

Froehner SC, Luetje CW, Scotland PB, Patrick J (1990) The postsynaptic $43 \mathrm{~K}$ protein clusters muscle nicotinic acetylcholine receptors in Xenopus oocytes. Neuron 5:403-410.

Gautam M, Mudd J, Copeland NG, Gilbert DJ, Jenkins NA, Merlie JP (1994) Characterization and mapping of the Rapsyn gene encoding the $43 \mathrm{kDa}$ acetylcholine receptor-associated protein. Genomics 24:366-369.

Gautam M, Noakes PG, Mudd J, Nichol M, Chu GC, Sanes JR, Merlie JP (1995) Failure of postsynaptic specialization to develop at neuromuscular junctions of rapsyn-deficient mice. Nature 377:232-236.

Goldman D, Deneris E, Luyten W, Kochhar A, Patrick J, Heinemann S (1987) Members of a nicotinic acetylcholine receptor gene family are expressed in different regions of the mammalian central nervous system. Cell 48:965-973.

Greene LA, Tischler AS (1976) Establishment of a noradrenergic clonal line of rat adrenal pheochromocytoma cells which respond to nerve growth factor. Proc Natl Acad Sci USA 73:2424-2428.

Horch HL, Sargent PB (1995) Perisynaptic surface distribution of multiple classes of nicotinic acetylcholine receptors on neurons in the chicken ciliary ganglion. J Neurosci 15:7778-7795.

Horch HL, Sargent PB (1996) Effects of denervation on acetylcholine receptor clusters on frog cardiac ganglion neurons as revealed by quantitative laser scanning confocal microscopy. J Neurosci 16:1720-1729.

Jacob MH, Berg DK (1983) The ultrastructural localization of alphabungarotoxin binding sites in relation to synapses on chick ciliary ganglion neurons. J Neurosci 3:260-271.

Kirsch J, Betz H (1993) Widespread expression of gephyrin, a putative glycine receptor-tubulin linker protein, in rat brain. Brain Res 621:301-310. 
Kirsch J, Kuhse J, Betz H (1995) Targeting of glycine receptor subunits to gephyrin-rich domains in transfected human embryonic kidney cells. Mol Cell Neurosci 6:450-461.

Kirsch J, Meyer G, Betz H (1996) Synaptic targeting of ionotropic neurotransmitter receptors. Mol Cell Neurosci 8:93-98.

Kistner U, Wenzel BM, Veh RW, Cases LC, Garner AM, Appeltauer U, Voss B, Gundelfinger ED, Garner CC (1993) SAP90, a rat presynaptic protein related to the product of the Drosophila tumor suppressor gene dlg-A. J Biol Chem 268:4580-4583.

Kornau HC, Seeburg PH, Kennedy MB (1997) Interaction of ion channels and receptors with PDZ domain proteins. Curr Opin Neurobiol 7:368-373.

LaRochelle WJ, Froehner SC (1986) Determination of the tissue distributions and relative concentrations of the postsynaptic $43 \mathrm{kDa}$ protein and the acetylcholine receptor in Torpedo. J Biol Chem 261:5270-5274.

Leber SM, Breedlove SM, Sanes JR (1990) Lineage, arrangement, and death of clonally related motoneurons in chick spinal cord. J Neurosci 10:2451-2462.

Lindstrom J (1996) Neuronal nicotinic acetylcholine receptors. Ion Channels 4:377-450.

Loring RH, Zigmond RE (1987) Ultrastructural distribution of ${ }^{125} \mathrm{I}-$ toxin $\mathrm{F}$ binding sites on chick ciliary neurons: synaptic localization of a toxin that blocks ganglionic nicotinic receptors. J Neurosci 7:2153-2162.

Maimone MM, Merlie JP (1993) Interaction of the $43 \mathrm{kd}$ postsynaptic protein with all subunits of the muscle nicotinic acetylcholine receptor. Neuron 11:53-66.

Mandelzys A, Pie B, Deneris ES, Cooper E (1994) The developmental increase in ACh current densities on rat sympathetic neurons correlates with changes in nicotinic $\mathrm{ACh}$ receptor $\alpha$-subunit gene expression and occurs independent of innervation. J Neurosci 14:2357-2364.

Mandelzys A, De Koninck P, Cooper E (1995) Agonist and toxin sensitivities of ACh-evoked currents on neurons expressing multiple nicotinic ACh receptor subunits. J Neurophysiol 74:1212-1221.

McGehee DS, Role LW (1995) Physiological diversity of nicotinic acetylcholine receptors expressed by vertebrate neurons. Annu Rev Physiol 57:521-546.

Musil LS, Frail DE, Merlie JP (1989) The mammalian 43 kDa acetylcholine receptor-associated protein (RAPsyn) is expressed in some nonmuscle cells. J Cell Biol 108:1833-1840.

Neubig RR, Krodel EK, Boyd ND, Cohen JB (1979) Acetylcholine and local anesthetic binding to Torpedo nicotinic postsynaptic membranes after removal of nonreceptor peptides. Proc Natl Acad Sci USA 76:690-694.

Niethammer M, Kim E, Sheng M (1996) Interaction between the C terminus of NMDA receptor subunits and multiple members of the PSD-95 family of membrane-associated guanylate kinases. J Neurosci 16:2157-2163.

Noakes PG, Phillips WD, Hanley TA, Sanes JR, Merlie JP (1993) 43K protein and acetylcholine receptors colocalize during the initial stages of neuromuscular synapse formation in vivo. Dev Biol 155:275-280.

Phillips WD, Kopta C, Blount P, Gardner PD, Steinbach JH, Merlie JP (1991a) ACh receptor-rich membrane domains organized in fibroblasts by recombinant 43-kilodalton protein. Science 251:568-570.
Phillips WD, Maimone MM, Merlie JP (1991b) Mutagenesis of the 43 $\mathrm{kDa}$ postsynaptic protein defines domains involved in plasma membrane targeting and AChR clustering. J Cell Biol 115:1713-1723.

Ramarao MK, Cohen JB (1997) Distinct structural domains within rapsyn are involved in self association and nicotinic acetylcholine receptor clustering. Soc Neursci Abstr 154:3.

Role LW, Berg DK (1996) Nicotinic receptors in the development and modulation of CNS synapses. Neuron 16:1077-1085.

Rubin E (1985) Development of the rat superior cervical ganglion: initial stages of synapse formation. J Neurosci 5:697-704.

Rust G, Burgunder JM, Lauterburg TE, Cachelin AB (1994) Expression of neuronal nicotinic acetylcholine receptor subunit genes in the rat autonomic nervous system. Eur J Neurosci 6:478-485.

Sanes JR (1997) Genetic analysis of postsynaptic differentiation at the vertebrate neuromuscular junction. Curr Opin Neurobiol 7:93-100.

Sargent PB, Pang DZ (1989) Acetylcholine receptor-like molecules are found in both synaptic and extrasynaptic clusters on the surface of neurons in the frog cardiac ganglion. J Neurosci 9:1062-1072.

Smolen A, Raisman G (1980) Synapse formation in the rat superior cervical ganglion during normal development and after neonatal deafferentation. Brain Res 181:315-323.

Sobel A, Weber M, Changeux JP (1977) Large-scale purification of the acetylcholine-receptor protein in its membrane-bound and detergentextracted forms from Torpedo marmorata electric organ. Eur J Biochem 80:215-224

Swanson LW, Simmons DM, Whiting PJ, Lindstrom J (1987) Immunohistochemical localization of neuronal nicotinic receptors in the rodent CNS. J Neurosci 7:3334-3342.

Tsuchida T, Ensini M, Morton SB, Baldassare M, Edlund T, Jessell TM, Pfaff SL (1994) Topographic organization of embryonic motor neurons defined by expression of LIM homeobox genes. Cell 79:957-970.

Wan Q, Xiong ZG, Man HY, Ackerley CA, Braunton J, Lu WY, Becker LE, MacDonald JF, Wang YT (1997) Recruitment of functional $\mathrm{GABA}_{\mathrm{A}}$ receptors to postsynaptic domains by insulin. Nature 388:686-690.

Wang F, Gerzanich V, Wells GB, Anand R, Peng X, Keyser K, Lindstrom J (1996) Assembly of human neuronal nicotinic receptor alpha5 subunits with alpha3, beta2, and beta4 subunits. J Biol Chem 271:17656-17665.

Whiting PJ, Liu R, Morley BJ, Lindstrom JM (1987) Structurally different neuronal nicotinic acetylcholine receptor subtypes purified and characterized using monoclonal antibodies. J Neurosci 7:4005-4016.

Wilson HH, Sargent PB (1996) Synaptic and extrasynaptic distribution of two distinct populations of nicotinic acetylcholine receptor clusters in the frog cardiac ganglion. J Neurocytol 25:67-77.

Yang SH, Armson PF, Cha J, Phillips WD (1997) Clustering of GABA receptors by rapsyn $/ 43 \mathrm{kDa}$ protein in vitro. Mol Cell Neurosci 8:430-438.

Zoli M, Le NN, Hill JJ, Changeux JP (1995) Developmental regulation of nicotinic ACh receptor subunit mRNAs in the rat central and peripheral nervous systems. J Neurosci 15:1912-1939. 